\title{
ВЛИЯНИЕ ПОЗИЦИЙ ВЫСШИХ СУДОВ НА УРОВЕНЬ ПРОЦЕДУРНО-ПРОЦЕССУАЛЬНЫХ ГАРАНТИЙ НАЛОГОПЛАТЕЛЬЩИКОВ (НА ПРИМЕРЕ ОТДЕЛЬНЫХ ЭТАПОВ ПРОЦЕДУРЫ ОФОРМЛЕНИЯ РЕЗУЛЬТАТОВ НАЛОГОВОЙ ПРОВЕРКИ) ${ }^{1}$
}

\author{
Зимулькин Максим Игоревич \\ Преподаватель, Уральский государственный \\ юридический университет, г. Екатеринбург \\ mi.zimulkin@gmail.com
}

Аннотация. В статье рассматриваются правовые последствия влияния позиций высших судов на уровень процедурно-процессуальных гарантий налогоплательщика. Автор раскрывает значимость процедурно-процессуальных положений законодательства Российской Федерации о налогах и сборах, указывает на сформулированную законодателем модель и представляет результаты ее реализации в правоприменительной практике. В качестве примера автор указывает на изменение правоприменительного подхода в части отдельных этапов оформления результатов налоговой проверки. По результатам исследования автор делает вывод об изменении ранее существовавшего правоприменительного подхода, умалении обязательности процедурно-процессуальных налогово-правовых норм и снижении заложенных законодателем гарантий прав налогоплательщиков.

Ключевые слова: налог, налоговый процесс, налоговые процедуры, налоговый контроль, судебная практика, акт налоговой проверки. 
C овременная юридическая наука отмечает особую роль процедурно-процессуальных норм законодательства Российской Федерации о налогах и сборах в механизме защиты прав налогоплательщиков [1;2], том числе при проведении отдельных мероприятий налогового контроля [3].

Процедурно-процессуальные положения налогового законодательства регламентируют, в частности, порядок проведения мероприятий налогового контроля, обеспечивая прозрачности деятельности налоговых органов, гарантии прав налогоплательщиков, а также баланс частных и публичных интересов.

Изложенное предопределяет необходимость исследования понятия существенности процедурно-процессуальных норм законодательства Российской Федерации о налогах и сборах при оформлении результатов налоговой проверки.

Безусловно, не каждое нарушение процедуры составления акта налоговой проверки или ознакомления с ним налогоплательщика, признается существенным нарушением и влечет безусловную отмену решения налогового органа. При этом буквальное толкование положений действующего законодательства не позволяет установить круг таких процедурно-процессуальных нарушений.

Вместе с тем, исследование достижений отечественной доктрины, а также анализ налогово-правовых норм и релевантной судебной практики порой позволяют выявить несоответствие заложенной законодателем модели, тому уровню процедурно-процессуальных прав, которые гарантированы налогоплательщику при правоприменении.

Как можно отметить, в действительности, существующие в настоящий момент правоприменительные подходы, сформировавшиеся на уровне высших судов, в некоторых случаях, закладывают новый смысл в процедурно-процессуальные налогово-правовые нормы, как следствие, влияя на уровень процедурно-процессуальных гарантий налогоплательщиков.

Изложенное, в частности, отмечается применительно к отдельным положениям законодательства Российской Федерации о налогах и сборах, регламентирующим порядок оформления результатов налоговой проверки.

Регламентация процедуры оформления результатов налоговой проверки осуществляется положениями статьи 100 НК РФ [4].

Указанные положения закрепляют порядок составления акта налоговой проверки, включая сроки соот- ветствующей процедуры, форму, содержание акта и порядок его вручения, а также порядок предоставления налогоплательщиком возражений на акт налоговой проверки.

Некоторые особенности процедуры оформления результатов налоговой проверки раскрываются в пунктах 28-31 Постановления Пленума ВАС РФ от 30.07.2013 № 57 «О некоторых вопросах, возникающих при применении арбитражными судами части первой Налогового кодекса Российской Федерации [5].

Кроме того, наиболее важные правовые проблемы оформления результатов налоговой проверки нашли свое отражение в отечественной доктрине [6;7;8;9;10;11].

Строгий порядок процедуры оформления результатов налоговой проверки обеспечивает баланс частных и публичных интересов, а также делает рассматриваемую процедуру открытой, понятной и прогнозируемой.

Безупречно описанный порядок оформления результатов налоговой проверки направлен на достижение технически точного механизма налоговой процедуры, исключающего возникновение необоснованной дискреции налоговых органов и злоупотреблений со стороны налогоплательщиков.

Однако, несмотря на обозначенную необходимость неукоснительного соблюдения процедурно-процессуальных норм, регламентирующих порядок оформления результатов налоговой проверки, актуальная судебная практика иногда нивелирует их значимость, не признавая, например, нарушение соответствующих норм существенным нарушением процедуры, влекущим отмену правоприменительных актов и признания действий (бездействий) должностных лиц налоговых органов незаконными.

В настоящее время можно выделить ряд нарушений, связанных с оформлением результатов проверки, которые наиболее часто являются основаниями для налоговых споров. Такими обстоятельствами представляются нарушение порядка вручения акта налоговой проверки, отсутствие в акте налоговой проверки необходимых сведений и отсутствие в акте налоговой проверки всех необходимых подписей должностных лиц налогового органа.

Обозначенный перечень проблем, связанных с оформлением результатов налоговой проверки, затрагивая наиболее насущные вопросы, не является исчерпывающим, так как обстоятельства конкретных дел позволяют постоянно выявлять новые проблемные аспекты. 
На основании пункта 5 статьи 100 НК РФ акт налоговой проверки должен быть в пятидневный срок лично вручен налогоплательщику или его представителю. Направление акта налоговой проверки посредством почтовой связи допускается только в случае уклонения налогоплательщика от личного получения акта [4].

До 2013 года (отдельные прецеденты возникали вплоть до 2015 года) в правоприменительной практике отслеживалась тенденция, определяющая, что направление акта налоговой проверки посредством почтовой связи в отсутствие указания в нем сведений о том, что налогоплательщик уклонился от получения акта налоговой проверки, является существенным нарушением процедурно-процессуальных норм, влекущим отмену правоприменительных актов налогового органа $[12 ; 13 ; 14 ; 15 ; 16 ; 17 ; 18]$.

Последующее изменение сформировавшегося подхода в судебной практике, в том числе, связано с выводами, содержащимися судебных актах и разъяснениях ВАС РФ.

Отправной точкой сдвига в правоприменительном подходе можно считать Определение Верховного Суда РФ от 12.03.2012 № ВАС-2118/12 по делу А32-21276/2010 [19], установившем, что направление акта налоговой проверки посредством почтовой связи без предварительной попытки личного вручения полностью соответствует закону.

Следует полагать, что именно указанное определение ВАС РФ заложило основу для последующего закрепления позиции, позволяющей налоговым органам, направлять акты налоговой проверки посредством почтовой связи.

Однако главным переломным моментом в правоприменительной практике следует считать возникновение разъяснений, содержащихся в пункте 29 Постановления Пленума ВАС РФ от 30.07.2013 № 57 «О некоторых вопросах, возникающих при применении арбитражными судами части первой Налогового кодекса Российской Федерации» [5].

Разъяснения Пленума ВАС РФ закрепили возможность направления акта налоговой проверки налогоплательщику путем использования почтовой связи не только в случае недобросовестных действий последнего, выражающихся в уклонении от получения акта, но и в случае любой «невозможности вручения» соответствующего акта [5].

Следует отметить, что «невозможность вручения» толкуется значительно шире, нежели уклонение нало- гоплательщика от вручения акта налоговой проверки, так как может быть вызвана, в частности, нахождением налогоплательщика в лечебном учреждении, ограничительными мерами, связанными с пандемиями и стихийными бедствиями, а также иными обстоятельствами, не исключающими добросовестности лица, в отношении которого проводится налоговая проверка.

Толкование положений пункта 5 статьи 100 НК РФ [4] в изложенном контексте, несомненно, снижает заложенные законодателем гарантии прав налогоплательщика.

Тем не менее, позиция ВАС РФ стала переломной для судебной практики, существенно изменив правоприменительный подход в рассматриваемых вопросах и став повсеместной $[20 ; 21 ; 22 ; 23 ; 24 ; 25 ; 26]$.

В настоящий момент, исходя из выводов релевантной судебной практики, налоговый орган имеет возможность, в нарушение прямого указания положений пункта 5 статьи 100 НК РФ, направить акт налоговой проверки налогоплательщику по адресу, указанному в Едином государственном реестре юридических лиц, даже не совершая попытки личного вручения указанного документа.

Изложенное позволяет сделать выводы об изменении ранее существовавшего правоприменительного подхода, умалении обязательности процедурно-процессуальных налогово-правовых норм и снижении заложенных законодателем гарантий прав налогоплательщиков.

Автору представляется, что сложившаяся ситуация стала возможной по причине неаккуратной рецепции отдельных положений пункта 5 статьи 100, пункта 9 статьи 101, пунктов 4 и 11 статьи 101.4 НК РФ с целью формулирования общего правила направления юридически значимых документов по итогам мероприятий налогового контроля в адрес налогоплательщиков.

Изложенное обосновывается тем, что если положения пункта 9 статьи 101 НК РФ предусматривают допустимость направления решения налогового органа посредством почтовой связи по причинам невозможности его личного вручения, то положения пункта 5 статьи 100 НК РФ предусматривают возможность такого способа направления только в случае уклонения налогоплательщика от личного вручения.

Следует полагать, что попытка ВАС РФ сформулировать единое правило для различных налоговых процедур посредством общей формулировки [5], не предполагавшая изначально принципиальных разъяснений в части оснований изменения способа направления 
акта налогового органа, привела к коренному перелому в правоприменительной практике.

Буквально следуя пункту 29 Постановления Пленума ВАС РФ от 30.07.2013 № 57 «О некоторых вопросах, возникающих при применении арбитражными судами части первой Налогового кодекса Российской Федерации» [5], суды игнорируют доводы налогоплательщиков о нарушении налоговыми органами процедуры оформления акта налоговой проверки в части вручения указанного документа, что, несомненно, нельзя признать соответствующим режиму законности, принципу прозрачности деятельности органов государственной власти, а также принципу разумных ожиданий и поддержания доверия к деятельности государственных органов.

Обозначенный подход, по мнению автора, недопустим и требует пересмотра.

Уровень процедурно-процессуальных гарантий налогоплательщиков может быть восстановлен изменением правоприменительного подхода, в первую очередь, на уровне Верховного Суда Российской Федерации и посредством обращения к буквальному толкованию положений законодательства Российской Федерации о налогах и сборах.

\section{ЛИТЕРАТУРА}

1. Винницкий Д.В. Налоговое процедурное право и налоговый процесс: проблемы становления / Д.В. Винницкий // Законодательство. 2003.— № 2.— C. $23-31$.

2. Демин А.В. Общая теория налогово-правовых норм: монография / А.В. Демин.— М.: РИОР: ИНФА-М, 2012. — 266 с.

3. Зимулькин М.И. Процедурно-процессуальные аспекты истребования налоговыми органами документов у контрагентов налогоплательщика // Евразийский юридический журнал. 2020. № 2 (141). С. 246-248.

4. «Налоговый кодекс Российской Федерации (часть первая)» от 31.07.1998 № 146-Ф3 (спосл. изм. и доп. на 20.07.2020) // СПС «КонсультантПлюс». Первоначальный текст опубликован в Рос. газ. № 148-149. 1998.

5. Постановление Пленума ВАС РФ от 30.07.2013 № 57 «0 некоторых вопросах, возникающих при применении арбитражными судами части первой Налогового кодекса Российской Федерации» // СПС «КонсультантПлюс».

6. Лысенко Д.В. Порядок подготовки возражений по акту налоговой проверки // Бухгалтерский учет в бюджетных и некоммерческих организациях. 2013. № 21 (333). С. 35-41.

7. Черник И. Письменные возражения на акт налоговой проверки // Налоговый вестник. 2012. № 9. Доступ из СПС «КонсультантПлюс».

8. Васькова, Е.П. Судебная оценка правовой природы акта налоговой проверки // Налоговед. 2011. № 2. С. 39.

9. Пепеляев, С.Г. Комментарий к Постановлению Пленума ВАС РФ от 12.10.2006 № 53 // Налоговед. 2007. № 2. С. 21-34.

10. Романова, А.Н. Организация и методы налоговых проверок: учеб. пособие / А.Н. Романова.— М., 2007.— 334 с.

11. Суворов М.А. Административно-процессуальная регламентация налоговых проверок: Дис. ... канд. юрид. наук. М., 2003. 175 С.

12. Постановление ФАС Уральского округа от 24.01.2011 № Ф09-10932/10-С2 по делу № А47-181/2010 // СПС «КонсультантПлюс».

13. Постановление ФАС Московского округа от 11.09.2012 по делу № А40-122546/11-116-328 // СПС «КонсультантПлюс».

14. Постановление ФАС Московского округа от 07.08.2013 по делу № А40-95693/12-90-491 // СПС «КонсультантПлюс».

15. Постановление ФАС Московского округа от 20.01.2014 № Ф05-16692/2013 по делу № А41-11771/10 // СПС «КонсультантПлюс».

16. Постановление АС Уральского округа от 02.03.2015 № Ф09-185/15 по делу № А60-5496/2014 // СПС «КонсультантПлюс».

17. Постановление ФАС Волго-Вятского округа от 11.12.2009 по делу № А28-7087/2009-163/23 // СПС «КонсультантПлюс».

18. Постановление ФАС Северо-Кавказского округа от 11.05 .2011 по делу № А53-16193/2010 // СПС «КонсультантПлюс».

19. Определение Верховного Суда РФ от 12.03.2012 № ВАС-2118/12 по делу А32-21276/2010 // СПС «КонсультантПлюс».

20. Определение Верховного Суда РФ от 04.04.2017 № 307-КГ17-2142 по делу № А04-5294/2017 // СПС «КонсультантПлюс».

21. Определение Верховного Суда РФ от 07.06.2018 № 303-КГ18-6840 по делу № А04-5294/2017 // СПС «КонсультантПлюС».

22. Постановление АС Северо-Западного округа от 01.12.2016 № Ф07-9765/2016 по делу № А56-96083/2015 // СПС «КонсультантПлюс»

23. Постановление АС Северо-Западного округа от 09.03.2017 № Ф07-9765/2016 по делу № А56-96083/2015 // СПС «КонсультантПлюс»

24. Постановление АС Дальневосточного округа от 08.02.2018 № Ф07-1007/2017 по делу № A56-44928/2016 // СПС «КонсультантПлюс»

25. Постановление АС Северо-Кавказского округа от 29.10.2018 № Ф08-8932/2018 по делу № А53-6874/2018 // СПС «КонсультантПлюс»

26. Постановление Семнадцатого арбитражного апелляционного суда от 11.02.2019 № 17АП-14536/2018-АК по делу № А60-26922/2018 // СПС «КонсультантПлюс» 